\title{
Sensitivity of Pythium irregulare, P. sylvaticum, and $P$. ultimum from Forest Nurseries to Mefenoxam and Fosetyl-Al, and Control of Pythium Damping-off
}

Jerry E. Weiland, United States Department of Agriculture-Agricultural Research Service (USDA-ARS), Horticulture Crops Research Laboratory and Department of Botany and Plant Pathology, Oregon State University, Corvallis 97331; Luisa Santamaria, Department of Botany and Plant Pathology, Oregon State University; and Niklaus J. Grünwald, USDA-ARS Horticulture Crops Research Laboratory and Department of Botany and Plant Pathology, Oregon State University

\begin{abstract}
Weiland, J. E., Santamaria, L., and Grünwald, N. J. 2014. Sensitivity of Pythium irregulare, P. sylvaticum, and P. ultimum from forest nurseries to mefenoxam and fosetyl-Al, and control of Pythium damping-off. Plant Dis. 98:937-942.

Mefenoxam and fosetyl-Al are common fungicides used to supplement disease control of Pythium damping-off and root rot in forest nurseries of the western United States. However, it is unknown whether fungicide-resistant Pythium isolates are present or whether new fungicide and biological treatments might also provide supplemental disease control. Isolates of Pythium irregulare, $P$. sylvaticum, and $P$. ultimum from three forest nurseries were evaluated for in vitro sensitivity to mefenoxam and fosetyl-Al. A greenhouse study was also conducted to assess efficacy of fungicide and biological treatments in Douglas-fir (Pseudotsuga menziesii) seedlings inoculated with Pythium dissotocum, $P$. irregulare, and $P$. 'vipa'. $P$. irregulare was approximately three times less sensitive to mefenoxam $(0.20 \mu \mathrm{g} / \mathrm{ml})$ than $P$. sylvaticum

$(0.06 \mu \mathrm{g} / \mathrm{ml})$ and $P$. ultimum $(0.06 \mu \mathrm{g} / \mathrm{ml})$, and two resistant isolates of P. ultimum were identified $(\geq 311 \mu \mathrm{g} / \mathrm{ml})$. All three Pythium spp. were similarly sensitive to fosetyl-Al $(1,256$ to $1,508 \mu \mathrm{g} / \mathrm{ml})$ and no resistant isolates were found. In the disease control efficacy trial, both fosetyl$\mathrm{Al}$ and phosphorous acid consistently provided good protection against damping-off caused by $P$. dissotocum, $P$. irregulare, and $P$. 'vipa'. Other treatments, including mefenoxam, also provided good or intermediate protection but efficacy depended upon which Pythium sp. was used. Growers should consider rotating mefenoxam use with other fungicide chemistries or biological treatments to prevent further development and spread of mefenoxam-resistant isolates.
\end{abstract}

Pythium spp. are regarded as one of the most important soilborne pathogens affecting tree seedling production in bareroot forest nurseries (6). Numerous Pythium spp., including Pythium dissotocum, $P$. irregulare, $P$. mamillatum, $P$. sylvaticum, and $P$. ultimum, have been isolated from forest nursery soils and seedlings $(12,17,35)$ and are associated with root lesions, damping-off, and root rot $(31,36)$. Disease control is primarily achieved via soil fumigation with a mixture of methyl bromide and chloropicrin or with dazomet (38). However, the fungicide mefenoxam is also frequently applied for supplemental disease control (J. Weiland, unpublished data). Occasionally, phosphonates such as fosetyl-Al (aluminum tris-O-ethyl phosphonate) or phosphorous acid are used (J. Weiland, unpublished data).

Mefenoxam, a phenylamide fungicide and the active R-isomer component of metalaxyl, specifically inhibits ribosomal RNA synthesis in oomycetes (5), whereas phosphonates, usually composed of the active ingredients fosetyl-Al or potassium phosphite, are thought to generally and nonspecifically affect oomycete species by toxicity to multiple nonspecific sites, and also are thought to stimulate certain plant host defenses (11). Mefenoxam resistance has been documented in several Pythium spp., including P. irregulare and $P$. ultimum, particularly in situations where use of the fungicide is common $(24,27,32)$. However, resistance to metalaxyl has also been found in Pythium isolates from fields where metalaxyl use was absent or infrequent (3); therefore, a similar occurrence might arise with the $\mathrm{R}$-isomer mefenoxam. In contrast, comparatively little research has been conducted regarding the presence

Corresponding author: J. Weiland, E-mail: Jerry.Weiland@ars.usda.gov

Accepted for publication 22 January 2014.

http://dx.doi.org/10.1094/PDIS-09-13-0998-RE

This article is in the public domain and not copyrightable. It may be freely reprinted with customary crediting of the source. The American Phytopathological Society, 2014. of phosphonate resistance in species of Pythium. Sanders et al. (29), for example, did not observe mycelial growth inhibition among 25 Pythium isolates, including $P$. dissotocum and $P$. irregulare, treated with fosetyl-Al at up to $100 \mu \mathrm{g} / \mathrm{ml}$. Similarly, Martinez et al. (21) characterized 14 isolates of $P$. macrosporum, $P$. sulcatum, and $P$. sylvaticum as generally insensitive to the fungicide at concentrations $\leq 100 \mu \mathrm{g} / \mathrm{ml}$.

Because of the prevalence of soil fumigation in the forest nursery industry $(14,17,38)$, comparatively little research has been focused on the efficacy of fungicides or biological treatments for the control of Pythium spp. affecting tree seedling production. Biological treatments (e.g., Trichoderma, Streptomyces, and Bacillus spp.) have been largely unsuccessful or inconsistent $(14,20,38)$. On the other hand, fungicides such as etridiazole or etridiazole plus thiophanate-methyl, mefenoxam, or metalaxyl and the phosphonates have proven effective $(16,20)$, while results with thiram and captan have been mixed $(7,20,34)$. However, most fungicide efficacy trials were conducted prior to the 1980 s, and there is little information about the efficacy of newer fungicide chemistries (e.g., the strobilurins) against the Pythium spp. that affect forest tree seedlings (20). As the frequency of methyl bromide fumigation continues to decline due to the Montreal Protocol and restrictions for soil fumigation increase, fungicides and other alternative disease control treatments (e.g., biological control, soil amendments, and so on) will likely play an increasingly important role in mitigating tree seedling damage caused by Pythium spp. (38).

Despite the widespread use of mefenoxam in forest nurseries, nothing is known about the range of mefenoxam sensitivity or whether mefenoxam resistance is present among Pythium spp. and isolates that are associated with tree seedling production. The same information is also lacking for the phosphonate fungicides. The effectiveness of mefenoxam and fosetyl-Al for supplemental control of tree seedling damping-off and root rot might be compromised if resistance to these commonly used fungicides develops. There may also be risk for the movement of fungicide-resistant isolates to new locations because nursery stock and equipment are frequently moved among nurseries. Therefore, the objectives of 
this research were to (i) determine the range of sensitivity among forest nursery isolates of $P$. irregulare, $P$. sylvaticum, and $P$. ultimum to mefenoxam and fosetyl-Al; (ii) determine whether species and locational differences in mefenoxam and fosetyl-Al sensitivity exist among $P$. irregulare, $P$. sylvaticum, and P. ultimum; (iii) determine whether there are isolates of $P$. irregulare, $P$. sylvaticum, and $P$. ultimum that are resistant to mefenoxam and fosetyl-Al; and, (iv) compare the efficacy of mefenoxam to other fungicide chemistries and biological treatments for the potential to reduce dampingoff severity of Douglas-fir (Pseudotsuga menziesii) seedlings.

\section{Materials and Methods}

Pythium isolates. Pythium isolates were originally obtained from the soil at three forest nurseries in Oregon and Washington in 2008 (35). Nursery A was located in southwestern Washington while nurseries B and C were located in northwestern Oregon. Isolates were obtained by dilution plating a soil solution onto PARP agar, a semiselective medium for Pythiaceous species (19), or by baiting submerged soil with rhododendron leaf disks and Douglas-fir needles (35). The isolates were then identified to species using the DNA sequence from the internal transcribed spacer (ITS) region and by morphology, according to methods described previously (35). All isolates were stored on colonized corn or water agar plugs in sterile water at $20^{\circ} \mathrm{C}$ and grown as active cultures on plates containing $20 \mathrm{ml}$ of potato dextrose agar (PDA).

Fungicide sensitivity assay. In all, 117 isolates of Pythium irregulare, $P$. sylvaticum, and $P$. ultimum were selected as representatives of three highly virulent (aggressive) pathogens of Douglas-fir, the most common tree species grown in forest nurseries of Oregon and Washington (36). Virulence, as used here, refers to the quantitative, relative ability of each isolate to cause disease. $P$. irregulare was isolated from all three forest nurseries (nursery $\mathrm{A}=20$ isolates, nursery $\mathrm{B}=18$ isolates, and nursery $\mathrm{C}=11$ isolates) whereas $P$. sylvaticum (nursery $\mathrm{B}=17$ isolates and nursery $\mathrm{C}=20$ isolates) and $P$. ultimum (nursery $\mathrm{B}=12$ isolates and nursery $\mathrm{C}=$ 19 isolates) were only isolated from two nurseries (Table 1). In addition, the three Pythium spp. used in the fungicide and biological treatment efficacy assay (one isolate each of $P$. dissotocum, $P$. irregulare, and $P$. 'vipa', below) were also assessed for their sensitivity to mefenoxam and fosetyl-Al.

The sensitivity of each isolate was evaluated in 84-mm-diameter petri plates containing $16 \mathrm{ml}$ of V8 juice agar amended with either mefenoxam (Subdue MAXX, 22\% a.i.; Syngenta Crop Protection: $0.1,1.0,5.0,10.0$, and $100 \mu \mathrm{g}$ a.i./ml) or fosetyl-Al (Aliette WDG, $80 \%$ a.i.; Bayer CropScience LP: 1, 500, 1,000, 1,500, 2,000, and
2,500 $\mu \mathrm{g}$ a.i./ml). The recommended label dose for Subdue MAXX was 19 to $38 \mu \mathrm{g}$ a.i./ml for foliar application or 758 to $1,516 \mu \mathrm{g}$ a.i./ml for soil surface application. For Aliette WDG, the recommended dose was 2,400 to $4,800 \mu \mathrm{g}$ a.i. $/ \mathrm{ml}$ for foliar application or 384 to $768 \mu \mathrm{g}$ a.i./ml for soil drenches. Plates containing nonamended V8 juice agar were used as negative controls. V8 juice agar was prepared with either $12 \mathrm{~g}$ of V8 juice broth (VWR International) and $15 \mathrm{~g}$ of agar/liter of distilled water or with $3.4 \mathrm{~g}$ of $\mathrm{CaCO}_{3}$ per $340 \mathrm{ml}$ of $\mathrm{V} 8$ filtered through eight layers of cheesecloth, diluted 1:4 with distilled water and $17 \mathrm{~g}$ of agar/liter. For each isolate-treatment combination, a single 5-mmdiameter colonized agar plug was cut from the margin of a 4- to 6day-old culture and then placed into the center of each replicate treatment plate. After 2 or 3 days of incubation (for mefenoxam or fosetyl-Al, respectively) at $22 \pm 1{ }^{\circ} \mathrm{C}$, the diameter of each culture was measured in two perpendicular directions to the nearest $\mathrm{mm}$. Then, after 7 days of incubation at $22 \pm 1^{\circ} \mathrm{C}$, a 5 -mm-diameter colonized agar plug was removed from each replicate plate of each isolate and transferred to a nonamended plate of V8 juice agar to evaluate whether mortality had occurred at each fungicide concentration level. Isolates that did not resume growth from the transferred, colonized agar plug within 2 weeks were rated as dead. All treatments, including the negative control, were replicated three times, and the entire experiment was repeated.

Fungicide and biological treatment efficacy assay. In order to address concerns about the management of the most commonly isolated Pythium spp. at each of the three forest nurseries (35), one isolate each of $P$. dissotocum (isolate 41-08, nursery C), $P$. irregulare (isolate 45-08, nursery A), and $P$. 'vipa' (isolate 09-08, nursery B) were evaluated for efficacy in control by specific fungicide or biological treatments. The isolate designated as $P$. 'vipa' had an ITS sequence with $99 \%$ maximum sequence identity to the ITS region of isolate 96-224 (DQ528743.1) in GenBank, which was originally assigned the name $P$. 'vipa' (13). Inoculum for each isolate was produced using a method modified from previous experiments $(36,37)$ by placing 3 liters of dry coarse vermiculite and 2.1 liters of dilute, clarified V8 juice $\left(6.8 \mathrm{~g}\right.$ of $\mathrm{CaCO}_{3}$ per $340 \mathrm{ml}$ of V8 juice, filtered through eight layers of cheesecloth, then mixing clarified V8 juice at $75 \mathrm{ml} /$ liter of distilled water) into fungal spawn bags (Fungi Perfecti). Bags were then autoclaved three times at 48-h intervals, and a single Pythium isolate was placed into each bag by cutting an entire plate containing a 1-week-old culture grown on $20 \mathrm{ml}$ of V8 juice agar into approximately 1.5$\mathrm{cm}^{2}$ pieces. Spawn bags were heat sealed and then incubated at $20^{\circ} \mathrm{C}$ in the dark for 60 days with weekly mixing by hand to main-

Table 1. Fungicide sensitivity of Pythium irregulare, P. sylvaticum, and P. ultimum to mefenoxam and fosetyl-Al

\begin{tabular}{|c|c|c|c|}
\hline \multirow[b]{2}{*}{ Species, nursery ${ }^{\mathrm{y}}$} & \multirow[b]{2}{*}{ Number of isolates } & \multicolumn{2}{|c|}{$\mathrm{EC}_{50} \mu \mathrm{g} / \mathrm{ml} \pm \mathrm{SE}(\text { range })^{\mathrm{x}}$} \\
\hline & & Mefenoxam & Fosetyl-Al \\
\hline \multicolumn{4}{|l|}{ P. irregulare } \\
\hline A & 20 & $0.19 \pm 0.012(0.07-0.51) \mathrm{a}$ & $1,239 \pm 11.5(1,082-1372) \mathrm{a}$ \\
\hline B & 18 & $0.25 \pm 0.016(0.07-0.56) \mathrm{a}$ & $1,257 \pm 12.3(990-1378) \mathrm{a}$ \\
\hline $\mathrm{C}$ & 11 & $0.13 \pm 0.016(0.05-0.44) \mathrm{a}$ & $1,285 \pm 13.0(1,211-1412)$ a \\
\hline All three nurseries & 49 & $0.20 \pm 0.009(0.05-0.56) \mathrm{A}$ & $1,256 \pm 7.2(990-1412) \mathrm{A}$ \\
\hline \multicolumn{4}{|l|}{ P. sylvaticum } \\
\hline $\mathrm{B}$ & 17 & $0.07 \pm 0.006(0.05-0.17) \mathrm{a}$ & $1,288 \pm 9.0(1,172-1376)$ а \\
\hline $\mathrm{C}$ & 20 & $0.06 \pm 0.001(0.05-0.07) \mathrm{a}$ & $1,335 \pm 11.9(1,180-1567)$ a \\
\hline Both nurseries & 37 & $0.06 \pm 0.003(0.05-0.17) \mathrm{B}$ & $1,314 \pm 7.8(1,172-1567) \mathrm{A}$ \\
\hline \multicolumn{4}{|l|}{ P. ultimum ${ }^{2}$} \\
\hline $\mathrm{B}$ & $11(12)$ & $0.05 \pm 0.001(0.05-0.06) \mathrm{a}$ & $1,525 \pm 16.4(1,406-1649)$ а \\
\hline $\mathrm{C}$ & $18(19)$ & $0.07 \pm 0.007(0.05-0.37) \mathrm{a}$ & $1,498 \pm 9.1(1,407-1652)$ а \\
\hline Both nurseries & $29(31)$ & $0.06 \pm 0.05(0.05-0.37) \mathrm{B}$ & $1,508 \pm 8.4(1,406-1652) \mathrm{A}$ \\
\hline
\end{tabular}

${ }^{\mathrm{x}} \mathrm{EC}_{50}$ is the concentration of fungicide required to reduce the culture diameter by half as compared with the nonamended control plate; $n=$ six replicate plates/isolate. Means followed by the same letter are not significantly different according to Tukey's test at $P=0.05$ among locations within each species separately (lowercase letters) or among species (uppercase letters).

${ }^{\mathrm{y}}$ Nursery A is located in southwestern Washington and nurseries B and C are located in northwestern Oregon.

${ }^{z}$ Means and mean separation tests for mefenoxam do not include two P. ultimum isolates (one each from nursery B and C) that were identified as outliers based on Dixon's test. These two isolates were not resistant to fosetyl-Al and, therefore, were included in means and means separation tests for fosetyl-Al. The number of isolates used to calculate mean P. ultimum $\mathrm{EC}_{50}$ values are indicated in front of the parentheses for mefenoxam and within the parentheses for fosetyl-Al. 
tain adequate aeration. Inoculum was removed from the bags, air dried for 2 days, and stored in resealable polyethylene bags at $20^{\circ} \mathrm{C}$ until used to infest soilless potting media.

In all, 11 fungicide or biological treatments and 3 control treatments were evaluated (Table 2) using methods adapted from Linderman et al. (20). The three control treatments were (i) a nontreated, inoculated control for each Pythium sp. (no fungicide or biological treatment to establish baseline seedling mortality associated with each Pythium spp.); (ii) a nontreated, noninoculated control (healthy check to establish average seed germination in the absence of disease); and (iii) a treated, noninoculated control (to evaluate each fungicide or biological treatment for potential phytotoxicity in the absence of disease). For the fungicide treatments, soilless potting media (OBC Northwest Seedling Mix number 1; OBC Northwest Inc.) was infested with each respective Pythium isolate $(10 \%$ [vol/vol] vermiculite inoculum/potting media), distributed into eight replicate $450-\mathrm{cm}^{3}$ polystyrene pots per treatment, then moistened slightly with water and allowed to rest for 5 days. Final population counts for each Pythium sp. in the infested soil were approximately 3,000 propagules per gram (ppg) of dry potting media. Fungicide treatments were then applied according to the rates in Table 2. For the two biological control treatments only (Trichoderma and Trichoderma + phosphorous acid), the potting media was first drenched with the respective biological control agent (Trichoderma harzianum strain T-22 and $T$. virens strain G-41) at the recommended rate 3 days prior to infesting the soilless media with the respective Pythium isolate (Table 2). Infested potting media was then distributed into eight replicate 450$\mathrm{cm}^{3}$ polystyrene pots per treatment. At this time, 10 cold-stratified Douglas-fir seeds were planted into each pot and the entire experiment was arranged according to a randomized complete block design with eight replicate blocks. Finally, phosphorous acid was applied to the Trichoderma + phosphorous acid treatment 14 days later, and select fungicides were reapplied after 14 to 28 days according to the schedule in Table 2. The entire experiment was repeated once. A preliminary report of the first experimental repeat has been published (9).

Data analyses. For the in vitro fungicide sensitivity experiment, the concentration of mefenoxam or fosetyl-Al required to reduce the culture diameter of each isolate by $50 \%\left(\mathrm{EC}_{50}\right.$ value) was calculated from plots of the culture diameters at each fungicide concentration. Isolates with mefenoxam $\mathrm{EC}_{50}$ values $\geq 100 \mu \mathrm{g} / \mathrm{ml}$ are considered resistant to that fungicide (24). A similar value has not been established for fosetyl-Al with Pythium spp., although many are considered insensitive to the fungicide with $\mathrm{EC}_{50}$ values of 100 to $\geq 500 \mu \mathrm{g} / \mathrm{ml}(21,29,33)$. $\mathrm{EC}_{50}$ values were analyzed by threeway analysis of variance (ANOVA) for effects of trial, species, isolate, and factor interactions using trial and isolate (nested within species) as random factors and species as a fixed factor. Because two isolates of P. ultimum (isolates Ult A2-2 and Ult C2-7) tested as outliers for resistance to mefenoxam (Dixon's test) and significantly skewed ANOVA results, these two isolates were omitted from further ANOVA tests involving mefenoxam sensitivity (30). For each Pythium sp. separately, isolates were further evaluated for an effect of location on fungicide sensitivity by including nursery as a fixed factor in the ANOVA model. Treatment means for all analyses were separated using Tukey's test at $P=0.05$.

For the in vivo fungicide efficacy experiment, the ability of each fungicide to reduce the incidence of damping-off was assessed by recording the number of healthy seedlings remaining in each replicate pot for each treatment 5 weeks after planting. These data were then converted into proportions (number of remaining healthy seedlings in each fungicide or biological treatment per average number of seedlings in the nontreated noninoculated control treatment) and then transformed by the arcsine of the square root to homogenize variances. Transformed data were analyzed for effects of trial, fungicide treatment, and interaction using two-way ANOVA, with trial as a random factor and fungicide treatment as a fixed factor. Fungicide and biological control treatments were also rated as providing good, intermediate, or poor protection against each Pythium isolate based on whether the percentage of surviving seedlings was statistically similar $(P \geq 0.05)$ to the nontreated, noninoculated control (good protection); similar to the nontreated, inoculated control (poor protection); or was significantly different $(P<0.05)$ from either control treatment (intermediate protection). Treatment means were separated using Tukey's test at $P=0.05$. All analyses were conducted with Minitab Statistical Software (release 15; Minitab Inc.) or SAS 9.2 (SAS Institute Inc.).

\section{Results}

Fungicide sensitivity assay. As a species, $P$. irregulare was approximately three times less sensitive $\left(\mathrm{EC}_{50}=0.20 \mu \mathrm{g} / \mathrm{ml}\right)$ to mefenoxam than either $P$. sylvaticum or P. ultimum $\left(\mathrm{EC}_{50}=0.06\right.$ $\mu \mathrm{g} / \mathrm{ml}$ for both species, $(P<0.001$; Table 1$)$. However, there was considerable variation in sensitivity among $P$. irregulare isolates $(P$ $<0.001$ ), with $16 / 49$ (33\%) of the P. irregulare isolates exhibiting the same low $\mathrm{EC}_{50}$ values $(0.05$ to $0.09 \mu \mathrm{g} / \mathrm{ml})$ that were found among the majority of $P$. sylvaticum and $P$. ultimum isolates; the

Table 2. Effect of fungicide and biological treatments on survival of Douglas-fir seedlings grown in soilless potting media infested with one of three Pythium spp.

\begin{tabular}{|c|c|c|c|c|c|c|}
\hline \multirow[b]{2}{*}{ Active ingredients } & \multirow[b]{2}{*}{ Trade name } & \multirow[b]{2}{*}{ Rate/liter } & \multirow[b]{2}{*}{$\begin{array}{l}\text { Reapplied } \\
{\text { (days })^{\mathrm{z}}}^{\text {(da) }}\end{array}$} & \multicolumn{3}{|c|}{ Surviving seedlings $(\%)(\mathrm{SE})^{\mathrm{y}}$} \\
\hline & & & & $\begin{array}{l}P \text {. dissotocum } \\
\text { isolate 41-08 }\end{array}$ & $\begin{array}{l}P \text {. irregulare } \\
\text { isolate } 45-08\end{array}$ & $\begin{array}{c}P . \text { 'vipa' } \\
\text { isolate 09-08 }\end{array}$ \\
\hline Noninoculated control & $\ldots$ & & & $100(7.5) \mathrm{a}$ & $100(7.5) \mathrm{a}$ & $100(7.5) \mathrm{a}$ \\
\hline Phosphorous acid & Alude & $1.00 \mathrm{ml}$ & 14 & $71(4.4) \mathrm{ab}$ & $67(8.2) \mathrm{ab}$ & 79 (6.9) ab \\
\hline Fosetyl-Al & Aliette WP & $0.72 \mathrm{~g}$ & $\ldots$ & $58(7.3) \mathrm{abc}$ & $69(8.8) \mathrm{ab}$ & 55 (7.1) abc \\
\hline Mefenoxam & Subdue MAXX & $0.08 \mathrm{ml}$ & 21 & $61(5.7) a b c$ & $60(8.8) a b c$ & 47 (6.9) bc \\
\hline $\begin{array}{l}\text { Trichoderma virens } \mathrm{G}-41 \\
\text { T. harzianum } \mathrm{T}-22\end{array}$ & RootShield Plus & $0.45 \mathrm{~g}$ & $\ldots$ & $35(6.7) \mathrm{cd}$ & $63(8.6) \mathrm{ab}$ & $44(8.6) b c$ \\
\hline Azoxystrobin & Heritage & $0.07 \mathrm{~g}$ & 21 & 57 (7.4) bc & $36(6.5) \mathrm{bcd}$ & $37(5.3) \mathrm{bcd}$ \\
\hline Fluopicolide & Adorn 4FL & $0.16 \mathrm{ml}$ & 14,28 & $21(4.6) \mathrm{d}$ & $26(6.2)$ cde & $46(8.6) \mathrm{bc}$ \\
\hline T. virens $G-41$ & RootShield Plus & $0.45 \mathrm{~g}$ & $\ldots$ & $39(5.6) \mathrm{bcd}$ & $33(7.5)$ bcde & $31(6.8) \mathrm{cd}$ \\
\hline T. harzianum $T-22+$ phosphorous acid & + Alude & $+1.00 \mathrm{ml}$ & $\ldots$ & $\ldots$ & $\ldots$ & $\ldots$ \\
\hline Fluoxastrobin & Disarm 480SC & $0.03 \mathrm{ml}$ & 14,28 & $30(4.3) \mathrm{cd}$ & $15(4.7) \mathrm{de}$ & $24(4.9) \mathrm{cd}$ \\
\hline Caprylic acid & $\operatorname{Cg} 100$ & $0.75 \mathrm{ml}$ & $\ldots$ & $31(5.9) \mathrm{cd}$ & $16(4.0) \mathrm{de}$ & $21(3.7) \mathrm{cd}$ \\
\hline Pyraclostrobin + boscalid & Pageant 38WG & $0.90 \mathrm{~g}$ & 14,28 & $16(5.0) \mathrm{d}$ & $18(5.2) \mathrm{de}$ & $16(4.3) \mathrm{cd}$ \\
\hline Fenamidone & Fenstop & $0.78 \mathrm{ml}$ & 28 & $14(4.3) \mathrm{d}$ & $19(5.3) \mathrm{de}$ & $14(3.7) \mathrm{cd}$ \\
\hline Inoculated control & $\ldots$ & $\ldots$ & $\ldots$ & $10(2.9) \mathrm{d}$ & $6(2.8) \mathrm{e}$ & $4(1.7) \mathrm{d}$ \\
\hline
\end{tabular}

${ }^{y}$ Mean percent surviving seedlings as a function of the nontreated, noninoculated control; $n=10$ Douglas-fir seed in each of 16 replicate pots; SE $=$ standard error. Seed were planted into pots containing soil infested with one of three Pythium spp. and treated with 1 of 11 fungicide or biological treatments. A nontreated, noninoculated control (Noninoculated control) and a nontreated, inoculated control (Inoculated control) were also included. Means within each column that share a letter are not significantly different according to Tukey's test at $P=0.05$.

${ }^{\mathrm{z}}$ Select fungicides were reapplied at 14,21 , or 28 days after initial treatment. 
remaining $P$. irregulare $\mathrm{EC}_{50}$ values ranged up to $0.56 \mu \mathrm{g} / \mathrm{ml}$. In comparison, there was no variation in sensitivity among isolates of $P$. sylvaticum $(P=0.310)$ and little variation among isolates of $P$. ultimum $(P<0.001)$. Most $P$. sylvaticum isolates $(28 / 31$ isolates or $90 \%)$ and $P$. ultimum isolates (35/37 or $95 \%)$ had $\mathrm{EC}_{50}$ values between 0.05 and $0.09 \mu \mathrm{g} / \mathrm{ml}$. However, two isolates of $P$. ultimum, isolate Ult A2-2 from nursery B and isolate Ult C2-7 from nursery $\mathrm{C}$, were approximately 5,000 to $6,000 \times$ more resistant to mefenoxam ( $\mathrm{EC}_{50}$ values of 375 and $311 \mu \mathrm{g} / \mathrm{ml}$, respectively) than all other P. ultimum isolates except isolate Ult C2-9 from nursery $\mathrm{C}$, with an EC value of $0.37 \mu \mathrm{g} / \mathrm{ml}$. Within each species separately, there was no evidence that isolate sensitivity to mefenoxam differed by location $(P \geq 0.218)$. Though culture diameter growth was inhibited completely with mefenoxam at $100 \mu \mathrm{g} / \mathrm{ml}$ for all Pythium isolates except Ult A2-2 and Ult C2-7, all isolates resumed growth when transferred to plates containing nonamended media. Therefore, none of the isolates were killed when exposed to mefenoxam at $100 \mu \mathrm{g} / \mathrm{ml}$. No trial effect $(P=0.583)$ or trial-species interaction $(P=0.916)$ was observed in the analyses. A small trial-isolate interaction was observed $(P<0.001)$ but results were similar when each trial was analyzed separately (data not shown).

In contrast to the mefenoxam sensitivity assay, all three Pythium spp. were similarly sensitive to fosetyl-Al $(P=0.060$; Table 1$)$. There was relatively little variation in fosetyl-Al sensitivity observed among isolates of $P$. irregulare and $P$. sylvaticum $(P \leq$ $0.010)$ and no variation among isolates of $P$. ultimum $(P=0.440)$. No resistant isolates were found for any of the three Pythium spp. and the two $P$. ultimum isolates that were highly resistant to mefenoxam, Ult A2-2 and Ult C2-7, were sensitive to fosetyl-A1. The $\mathrm{EC}_{50}$ values for these two isolates $(1,513$ and $1,390 \mu \mathrm{g} / \mathrm{ml}$, respectively) were similar to those of all other $P$. ultimum isolates tested on fosetyl-Al $(1,406$ to $1,652 \mu \mathrm{g} / \mathrm{ml})$. Within each species separately, there was no evidence that isolate sensitivity to fosetylAl differed by location $(P \geq 0.125)$. Culture diameter growth was inhibited completely with fosetyl-Al at $2,500 \mu \mathrm{g} / \mathrm{ml}$ for $47 / 49$ (96\%) of $P$. irregulare isolates and 35/37 (95\%) of $P$. sylvaticum isolates. All except three $P$. irregulare isolates resumed growth when transferred to plates containing nonamended media. In contrast, the culture diameter growth of only 9/31 (29\%) of P. ultimum isolates was inhibited completely with fosetyl-Al at $2,500 \mu \mathrm{g} / \mathrm{ml}$. All except one isolate of $P$. ultimum resumed growth when transferred to plates containing nonamended media. Therefore, only four Pythium isolates were killed when exposed to fosetyl-Al at $2,500 \mu \mathrm{g} / \mathrm{ml}$. No trial effect was observed $(P=0.419)$. Although small trial-species and trial-isolate interactions were observed $(P$ $<0.001$ ), results were similar when each trial was analyzed separately (data not shown).

Fungicide and biological treatment efficacy assay. The sensitivity of each of the three Pythium isolates used in the fungicide and biological treatment assay ( $P$. dissotocum 41-08, $P$. irregulare 45-08, and $P$. 'vipa' 09-08) to mefenoxam and fosetyl-Al was comparable with the $\mathrm{EC}_{50}$ values found for $P$. irregulare, $P$. sylvaticum, and $P$. ultimum isolates in the fungicide sensitivity assay. $P$. irregulare isolate 45-08 (nursery A) was similar in sensitivity to mefenoxam and fosetyl-Al $(0.19 \pm 0.05$ and $1,097 \pm 9.7 \mu \mathrm{g} / \mathrm{ml}$, respectively) compared with all other $P$. irregulare isolates from nursery A (Table 1). In contrast, $P$. dissotocum isolate 41-08 and $P$. 'vipa' isolate $09-08$ were more sensitive to mefenoxam $(0.009 \pm$ 0.0002 and $0.007 \pm 0.0001 \mu \mathrm{g} / \mathrm{ml}$, respectively) than all other isolates tested, regardless of species. However, these two isolates were just as sensitive to fosetyl-Al $(1,162 \pm 10.8$ and $1,119 \pm 9.7 \mu \mathrm{g} / \mathrm{ml}$, respectively) as all other Pythium isolates tested, regardless of species.

$P$. dissotocum, $P$. irregulare, and $P$. 'vipa' caused similar amounts of damping-off on Douglas-fir seed planted in the nontreated, inoculated control pots. $P$. dissotocum reduced seedling survival by $90 \%, P$. irregulare by $94 \%$, and $P$. 'vipa' by $96 \%$. Two fungicide treatments, phosphorous acid and fosetyl-Al, consistently provided good protection against damping-off, regardless of which Pythium spp. was used, and seedling survival in both treatments was similar to that of the nontreated, noninoculated control $(P \geq$ 0.050 ; Table 2). A similar level of protection was also provided by mefenoxam against $P$. dissotocum and $P$. irregulare but not against $P$. 'vipa'. Likewise, the Trichoderma biological treatment (consisting of $T$. harzianum and $T$. virens) provided good protection against $P$. irregulare but not against $P$. dissotocum or $P$. 'vipa'. Intermediate levels of protection were provided by mefenoxam against $P$. 'vipa', by the Trichoderma biological treatment against $P$. 'vipa', by fluopicolide against $P$. 'vipa', and by azoxystrobin against both $P$. dissotocum and $P$. irregulare. All other fungicide or biological control treatments were no different than the nontreated, inoculated control pots and, therefore, provided poor protection against damping-off by these three Pythium spp. No effects of reduced germination or phytotoxicity were observed for any of the 11 fungicide or biological treatments in the treated noninoculated controls (data not shown). Although trial effects were observed $(P<0.001)$, the differences were due to increased germination in trial 2 compared with trial 1 and results were consistent within each trial separately (data not shown). No trial-treatment interactions were observed $(P$ $\geq 0.088$ ).

\section{Discussion}

The range of mefenoxam sensitivity observed among Pythium spp. and isolates of forest nurseries was consistent with those reported from mefenoxam studies in other agricultural systems. In Idaho, Oregon, and Washington, the mefenoxam sensitivity of 68 P. ultimum isolates obtained from infected potato tubers ranged from $<0.05$ to $>100 \mu \mathrm{g} / \mathrm{ml}$, with 64 isolates having $\mathrm{EC}_{50}$ values $<1.0 \mu \mathrm{g} / \mathrm{ml}$ (32). Wheeler et al. (39) found that Pythium spp. from peanut ranged in sensitivity to mefenoxam from 0.001 to 0.270 $\mu \mathrm{g} / \mathrm{ml}$, and isolates of $P$. irregulare were less sensitive to mefenoxam $(0.049$ to $0.173 \mu \mathrm{g} / \mathrm{ml})$ than those of $P$. ultimum $(0.005$ and $0.006 \mu \mathrm{g} / \mathrm{ml}$ ), which was similar to our observations. However, the number of isolates evaluated for each species was extremely limited (two and five isolates, respectively) and another study found no differences in sensitivity between $P$. irregulare, $P$. sylvaticum, and $P$. ultimum from corn and soybean (4). Similar mefenoxam $\mathrm{EC}_{50}$ values have been reported from Phytophthora spp., including Phytophthora capsici ( 0.12 to $863 \mu \mathrm{g} / \mathrm{ml}), P$. drechsleri (initially reported as $P$. cryptogea, 0.1 to $549.5 \mu \mathrm{g} / \mathrm{ml}$ ), and $P$. erythroseptica $(<1.0$ to $205 \mu \mathrm{g} / \mathrm{ml})(15,25,26,32)$.

Less information is available about the range of fosetyl-Al sensitivity among Phytophthora and Pythium spp. For carrot cavity spot, Martinez et al. (21) found that the sensitivity of three Pythium spp. (Pythium macrosporum, P. sulcatum, and P. sylvaticum) to fosetyl-Al ranged from 97.6 to $>500 \mu \mathrm{g} / \mathrm{ml}$. All three $P$. sylvaticum isolates from that study had $\mathrm{EC}_{50}$ values $>500 \mu \mathrm{g} / \mathrm{ml}$ and were considered insensitive to the fungicide. In turfgrass, eight Pythium spp., including $P$. dissotocum and $P$. ultimum, were not inhibited by concentrations of fosetyl-Al up to $100 \mu \mathrm{g} / \mathrm{ml}$ (29). However, higher concentrations of the fungicide were not evaluated and final $\mathrm{EC}_{50}$ values were not reported. Therefore, it is not known how the sensitivity of those isolates compares with $P$. ultimum isolates in our study. Similar fosetyl-Al EC 50 values have been reported for Phytophthora spp., including Phytophthora citrophthora (24 to 285 $\mu \mathrm{g} / \mathrm{ml})$, P. infestans $(62$ to $1,021 \mu \mathrm{g} / \mathrm{ml})$, and P. parasitica $(1,146$ $\mu \mathrm{g} / \mathrm{ml})(2,8,22)$.

The presence of two mefenoxam-resistant isolates of Pythium ultimum, one at each Oregon nursery, indicates that there is risk that the fungicide may fail to provide adequate disease control in the future, especially if mefenoxam continues to be the primary fungicide used for supplemental disease control in forest nurseries. In other crops, mefenoxam (or metalaxyl) resistance has been discovered in many of the Pythium spp. that are also known to occur in forest nurseries, including $P$. dissotocum, $P$. irregulare, $P$. sylvaticum, and $P$. ultimum $(1,21,24,32)$. Moorman et al. (24), for example, found that $36 \%$ (21/59 isolates) of the P. irregulare isolates collected from greenhouse floral crops in Pennsylvania were resistant to mefenoxam as well as a single isolate each of $P$. dissotocum and P. ultimum. In contrast, Taylor et al. (32) rarely found 
resistant $P$. ultimum isolates in their survey of infected potato tubers. Only $3 \%$ (2/68 isolates) of the isolates from Idaho, Oregon, and Washington were characterized as mefenoxam resistant. Previous work on the related oomycete genus Phytophthora also established that resistance to metalaxyl could result in detectable selection for fungicide resistance within a single growing season (10). These prior results support our concern for risk in continued use of mefenoxam in seedling nurseries for control of Pythium spp.

There is little equivalent data for fosetyl-Al resistance in Pythium spp. Although Martinez et al. (21) characterized P. sylvaticum isolates as not sensitive based on $\mathrm{EC}_{50}$ values that were $>500$ $\mu \mathrm{g} / \mathrm{ml}$, it is not known how well these values correspond to actual disease control. Sanders et al. (29), however, reported that fosetylAl soil drenches were ineffective at reducing Pythium blight severity on perennial ryegrass inoculated with $P$. aphanidermatum isolates that were insensitive to the fungicide at $100 \mu \mathrm{g} / \mathrm{ml}$ (29). On the other hand, foliar sprays with fosetyl-Al were somewhat effective at reducing disease severity, which may have been indicative of the fungicide's ability to stimulate host defenses instead of being directly toxic to the pathogen. Similar reports of reduced sensitivity to fosetyl-Al have also been reported from Pythium spp. on turfgrass in Italy (33). Finally, resistance to fosetyl-Al was induced in a field isolate of $P$. aphanidermatum via chemical mutagenesis with $N$-methyl- $N$-nitro- $N$-nitrosoguanidine (28). The resultant mutant isolates had $\mathrm{EC}_{50}$ values of 3,000 to $4,700 \mu \mathrm{g} / \mathrm{ml}$ for phosphorous acid and were capable of causing disease on creeping bentgrass treated with fosetyl-Al. In our study, all $\mathrm{EC}_{50}$ values for fosetyl-Al were $\geq 990 \mu \mathrm{g} / \mathrm{ml}$ but the fosetyl-Al soil drench was still one of the most effective treatments to control Douglas-fir damping-off in the fungicide and biological treatment efficacy assay.

Our results from the fungicide and biological treatment efficacy assay confirm that the phosphonates and mefenoxam continue to be effective for reducing Douglas-fir damping-off caused by Pythium spp. $(16,20)$. In contrast to Linderman et al. (20), we found that azoxystrobin provided intermediate protection against $P$. irregulare (as well as $P$. dissotocum). Fluopicolide also provided intermediate protection but only against $P$. 'vipa'. To our knowledge, this is the first time that this fungicide has been tested against Pythium spp. from forest nurseries. Finally, we found that the biological treatment consisting of $T$. virens strain G-41 and $T$. harzianum strain T-22 provided good protection against $P$. irregulare, intermediate protection against $P$. 'vipa', but no protection against $P$. dissotocum. However, T. harzianum strain T-22 alone was ineffective against damping-off caused by a different isolate of $P$. irregulare in the Linderman et al. (20) study. These differences in efficacy among Pythium spp. and isolates might partially explain why disease control with $T$. harzianum has been lacking in the field where multiple Pythium spp. and isolates are present (18). The addition of $T$. virens strain G-41 to $T$. harzianum strain T-22 might also have improved efficacy against $P$. irregulare specifically. However, further studies are needed to elucidate how Pythium spp. and isolate diversity affects biological control.

In contrast to the results from our previous pathogenicity research, where $P$. dissotocum isolate 41 and $P$. 'vipa' isolate 9 caused little to no Douglas-fir seedling mortality (36), over $90 \%$ seedling mortality was observed with both isolates in the present study. P. irregulare also caused much greater seedling mortality in this study (90\%) than was observed previously (38\%). This was likely due to the much greater inoculum pressure obtained in the present study (approximately 3,000 ppg with the 10\% inoculum amendment rate) than was used in our preceding study (100 ppg), and suggests that both $P$. dissotocum and $P$. 'vipa' may act as aggressive pathogens when high inoculum densities are present. The inoculum amendment rate used in this study was the same as that used by Linderman et al. (20) to evaluate fungicide and biological treatments for efficacy in controlling damping-off of Douglas-fir seedlings with a different isolate of $P$. irregulare. In that study, seedling survival was reduced up to $45 \%$ in infested soil without a fungicide or biological treatment as compared with noninoculated controls. However, the final count of Pythium propagules in in- fested soil was not reported; therefore, a direct comparison of seedling mortality as a function of inoculum density is not possible. Although the inoculum density in this study was greater than that usually found in the field $(<300 \mathrm{ppg})$, Pythium populations can increase dramatically after incorporating organic matter into the soil. For example, populations of up to $1,100 \mathrm{ppg}$ were observed in field soils following a pea cover crop at a forest nursery in Washington (12), and populations of up to 4,486 ppg were noted in apple orchard soils amended with Brassica napus seed meal (23). Nevertheless, the efficacy of mefenoxam, fosetyl-Al, and phosphorous acid in reducing damping-off under high inoculum pressure in this study is consistent with the efficacy observed from other forest nursery fungicide studies $(16,20)$. It is likely that these fungicides will continue to perform satisfactorily against the lower inoculum levels that are usually found in the field as long as a substantial proportion of the Pythium community at each nursery does not develop resistance to each fungicide.

The mefenoxam and fosetyl-Al data presented here establish the baseline range of sensitivity for three highly virulent Pythium spp.: $P$. irregulare, $P$. sylvaticum, and P. ultimum. This information will be useful in monitoring for changes in fungicide sensitivity in forest nursery Pythium communities and will allow growers to determine whether the proportion of resistant isolates increases over time. This study also provides alternative fungicide and biological treatment options for the control of Pythium spp. If mefenoxam resistance becomes more prevalent in the forest nursery industry, these treatments may help provide supplemental control. However, none of the alternative treatments tested in our study provided as much protection as either mefenoxam or the phosphonates. Therefore, growers should focus on rotating fungicides with different modes of action to help reduce the further development of fungicide-resistant isolates.

\section{Acknowledgments}

Funding for this research was provided by USDA CRIS 303-5358-12220003-00D, the Pacific Area Wide Pest Management Program for Methyl Bromide Alternatives, and The IR-4 Project. We thank A. Bernert, K. Rolfe, A. Davis, and B. Beck for technical assistance.

\section{Literature Cited}

1. Allain-Boulé, N., Lévesque, C. A., Martinez, C., Bélanger, R. R., and Tweddell, R. J. 2004. Identification of Pythium species associated with cavityspot lesions on carrots in eastern Quebec. Can. J. Plant Pathol. 26:365-370.

2. Bashan, B., Levy, Y., and Cohen, Y. 1990. Variation in sensitivity of Phytophthora infestans to fosetyl-Al. Plant Pathol. 39:134-140.

3. Brantner, J. R., and Windels, C. E. 1998. Variability in sensitivity to metalaxyl in vitro, pathogenicity, and control of Pythium spp. on sugar beet. Plant Dis. 82:896-899.

4. Broders, K. D., Lipps, P. E., Paul, P. A., and Dorrance, A. E. 2007. Characterization of Pythium spp. associated with corn and soybean seed and seedling disease in Ohio. Plant Dis. 91:727-735.

5. Davidse, L. C. 1988. Phenylamide fungicides: mechanism of action and resistance. Pages 63-65 in: Fungicide Resistance in North America. C. J. Delp, ed. American Phytopathological Society, St. Paul, MN.

6. Dumroese, R. K., and James, R. L. 2005. Root diseases in bareroot and container nurseries of the Pacific Northwest: epidemiology, management, and effects on outplanting performance. New For. 30:185-202.

7. Enebak, S. A., Palmer, M. A., and Blanchette, R. A. 1990. Managing soilborne pathogens of white pine in a forest nursery. Plant Dis. 74:195-198.

8. Farih, A., Tsao, P. H., and Menge, J. A. 1981. Fungitoxic activity of efosite aluminum on growth, sporulation and germination of Phytophthora parasitica and P. citrophthora. Phytopathology 71:934-936.

9. Grünwald, N. J., Press, C. M., Rolfe, K., Weiland, J. E., and Davis, A. 2013. Efficacy of management tools for control of Pythium root rot of Douglas-fir seedlings, 2010. Plant Dis. Manage. Rep. 7:OT010.

10. Grünwald, N. J., Sturbaum, A. K., Montes, G. R., Serrano, E. G., LozoyaSaldaña, H., and Fry, W. E. 2006. Selection for fungicide resistance within a growing season in field populations of Phytophthora infestans at the center of origin. Phytopathology 96:1397-1403.

11. Guest, D., and Grant, B. 1991. The complex action of phosphonates as antifungal agents. Biol. Rev. 66:159-187.

12. Hansen, E. M., Myrold, D. D., and Hamm, P. B. 1990. Effects of soil fumigation and cover crops on potential pathogens, microbial activity, nitrogen availability, and seedling quality in conifer nurseries. Phytopathology 80:698-704.

13. Hermansen, A., Herrero, M. L., Gauslaa, E., Razzaghian, J., Nærstad, R., and Klemsdal, S. S. 2007. Pythium species associated with cavity spot on 
carrots in Norway. Ann. Appl. Biol. 150:115-121.

14. Hildebrand, D. M., Stone, J. K., James, R. L., and Frankel, S. J. 2004. Alternatives to preplant soil fumigation for Western forest nurseries. USDA Forest Service, Pacific Northwest Research Station. Gen. Tech. Rep. PNWGTR-608.

15. Hwang, J., and Benson, D. M. 2005. Identification, mefenoxam sensitivity, and compatibility type of Phytophthora spp. attacking floriculture crops in North Carolina. Plant Dis. 89:185-190.

16. James, R. L. 1982. Pythium root disease of Douglas-fir and grand fir seedlings at the Coeur d'Alene Nursery, Idaho. For. Health Prot. Rep. No. 8210 .

17. James, R. L. 2002. Effects of spring applications of dazomet on root diseases and performance of Douglas-fir and western white pine transplants at the USDA Forest Service Nursery, Coeur d'Alene, Idaho. For. Health Prot. Rep. 02-9.

18. James, R. L., Knudsen, G. R., and Morra, M. J. 2004. Preplant soil treatment effects on production of Douglas-fir seedlings at the USDA Forest Service Nursery, Coeur d'Alene, Idaho. For. Health Prot. Rep. 04-10.

19. Kannwischer, M. E., and Mitchell, D. J. 1978. The influence of a fungicide on the epidemiology of black shank of tobacco. Phytopathology 68:17601765 .

20. Linderman, R. G., Masters, C. J., and Davis, E. A. 2008. Efficacy of chemical and biological agents to suppress Fusarium and Pythium damping-off of container-grown Douglas-fir seedlings. Plant Health Progress. Online publication. doi:10.1094/PHP-2008-0317-1002-RS

21. Martinez, C., Lévesque, C. A., Bélanger, R. R., and Tweddell, R. J. 2005. Evaluation of fungicides for the control of carrot cavity spot. Pest Manage. Sci. 61:767-771.

22. Matheron, M.-E., and Porchas, M. 2000. Impact of azoxystrobin, dimethomorph, fluazinam, fosetyl-Al, and metalaxyl on growth, sporulation, and zoospore cyst germination of three Phytophthora spp. Plant Dis. 84:454458.

23. Mazzola, M., Brown, J., Zhao, X. W., Izzo, A. D., and Fazio, G. 2009. Interaction of brassicaceous seed meal and apple rootstock on recovery of Pythium spp. and Pratylenchus penetrans from roots grown in replant soils. Plant Dis. 93:51-57.

24. Moorman, G. W., Kang, S., Geiser, D. M., and Kim, S. H. 2002. Identification and characterization of Pythium species associated with greenhouse floral crops in Pennsylvania. Plant Dis. 86:1227-1231.

25. Olson, H. A., Carbone, I., and Benson, D. M. 2011. Phylogenetic history of Phytophthora cryptogea and P. drechsleri isolates from floriculture crops in North Carolina greenhouses. Phytopathology 101:1373-1384.
26. Parra, G., and Ristaino, J. B. 2001. Resistance to mefenoxam and metalaxyl among field isolates of Phytophthora capsici causing Phytophthora blight of bell pepper. Plant Dis. 85:1069-1075.

27. Reeleder, R. D., Miller, J. S., Capell, B., and Schooley, J. 2007. Mefenoxam sensitivity and the impact of fumigation on Pythium species and Phy tophthora cactorum in ginseng soils. Can. J. Plant Pathol. 29:427-436.

28. Sanders, P. L., Coffey, M. D., Greer, G. D., and Soika, M. D. 1990. Laboratory-induced resistance to fosetyl-Al in a metalaxyl-resistant field isolate of Pythium aphanidermatum. Plant Dis. 74:690-692.

29. Sanders, P. L., Houser, W. J., and Cole, H., Jr. 1983. Control of Pythium spp. and Pythium blight of turfgrass with fosetyl aluminum. Plant Dis. 67:1382-1383.

30. Sokal, R. R., and Rohlf, F. J. 2012. Biometry, Fourth Edition. W. H. Freeman and Company, New York.

31. Sutherland, J., and Dennis, J. 1992. Pythium water mould in British Columbia forest nurseries. Seed Seedling Ext. Topics 5:9-10.

32. Taylor, R. J., Salas, B., Secor, G. A., Rivera, V., and Gudmestad, N. C. 2002. Sensitivity of North American isolates of Phytophthora erythroseptica and Pythium ultimum to mefenoxam (metalaxyl). Plant Dis. 86:797802.

33. Titone, P., Mocioni, M., Garibaldi, A., and Gullino, M. L. 2009. Fungicide failure to control Pythium blight on turf grass in Italy. J. Plant Dis. Prot. 116:55-59.

34. Vaartaja, O. 1956. Screening fungicides for controlling damping-off of tree seedlings. Phytopathology 46:387-390.

35. Weiland, J. E. 2011. Influence of isolation method on recovery of Pythium species from forest nursery soils in Oregon and Washington. Plant Dis. 95:547-553.

36. Weiland, J. E., Beck, B. R., and Davis, A. 2013. Pathogenicity and virulence of Pythium species obtained from forest nursery soils on Douglas-fir seedlings. Plant Dis. 97:744-748.

37. Weiland, J. E., Leon, A. L., Edmonds, R. L., Littke, W. R., Browning, J. E. Davis, A., Beck, B. R., Miller, T. W., Cherry, M. L., and Rose, R. 2011. The effects of methyl bromide alternatives on soil and seedling pathogen populations, weeds, and seedling morphology in Oregon and Washington forest nurseries. Can. J. For. Res. 41:1885-1896.

38. Weiland, J. E., Littke, W. R., and Haase, D. L. 2013. Forest nurseries face critical choices with the loss of methyl bromide fumigation. Calif. Agric. 67:153-161.

39. Wheeler, T. A., Howell, C. R., Cotton, J., and Porter, D. 2005. Pythium species associated with pod rot on west Texas peanuts and in vitro sensitivity of isolates to mefenoxam and azoxystrobin. Peanut Sci. 32:9-13. 